\title{
Reaksi Pasar Atas Pengumuman Stock split
}

\author{
Putu Gede Aditama Putra ${ }^{1}$ \\ I Gusti Ngurah Agung Suaryana ${ }^{2}$
}

\author{
${ }^{1,2}$ Fakultas Ekonomi dan Bisnis Universitas Udayana (Unud), Bali, Indonesia \\ e-mail: tudeaditama@gmail.com
}

\begin{abstract}
ABSTRAK
Setiap aksi korporasi yang dilakukan oleh perusahaan memiliki potensi kandungan informasi sebagai suatu sinyal. Tujuan penelitian ini adalah untuk menguji kembali reaksi pasar atas pengumuman stock split yang di proksikan dengan menggunakan abnormal return. Pengujian kandungan informasi akan dilakukan dengan melihat signifikansi cumulative abnormal return.Penelitian ini dilakukan pada 65 perusahaan yang terdaftar di Bursa Efek Indonesia yang melakukan stock split tahun 2013-2017. Metode penentuan sampel yaitu dengan teknik nonprobability purposive sampling. Teknik analisis data yang digunakan adalah uji One Sample t-test. Hasil penelitian ini menunjukkan terdapat reaksi pasar atas pengumuman stock split. Hal ini ditunjukan dengan adanya abnormal return di sekitar pengumuman stock split. Hasil Penelitian ini secara teoretis dapat memberikan bukti empiris yang menguatkan signaling theory bahwa informasi yang dipublikasikan emiten direaksi oleh pasar, yang menunjukkan bahwa setiap informasi akuntansi yang masuk ke pasar modal memiliki kandungan informasi.
\end{abstract}

Kata kunci: Stock split, abnormal return.

\section{ABSTRACT}

Every corporate action carried out by a company has the potential for information content as signal. The purpose of this study is to reexamine the market reaction to the announcement of the stock split proxied by using abnormal return. Testing information content will be done by looking at the cumulative abnormal return significance. The method of determining the sample is by nonprobability purposive sampling technique. The data analysis technique used was the One Sample t-test. The results of this study indicate there is a market reaction to the announcement of the stock split. This is indicated by the existence of abnormal returns around the announcement of the stock split. The results of this study theoretically can provide empirical evidence that strengthens the signaling theory that the information published by the issuer is reacted by the market, which shows that any accounting information that enters the capital market has information content.

Keywords: Stock split, abnormal return.

\section{PENDAHULUAN}

Pasar modal didefinisikan sebagai pasar untuk berbagai instrument keuangan (atau sekuritas) jangka panjang yang bisa diperjual belikan, baik dalam bentuk hutang maupun modal sendiri, baik yang diterbitkan oleh pemerintah, public authorities, maupun perusahaan swasta (Husnan, 1998:3). Pasar modal adalah salah satu 
sarana untuk melakukan investasi. Bagi investor tujuan investasi melalui pasar modal adalah untuk mendapatkan tingkat pengembalian (return) investasi yang optimal. Investor dapat memilih perusahaan mana yang nantinya mereka akan tananamkan uangnya atau modalnya agar memperoleh keuntungan maksimal. Investor akan menyalurkan dananya kepada perusahaan dan untuk mendapatkan dana dari pasar modal, perusahaan harus go public terlebih dahulu. Dengan menginvestasikan dananya ke perusahaan yang tercatat di pasar modal, investor tentunya akan mengharapkan adanya return (imbalan).

Pasar modal memberikan banyak informasi yang dapat diperoleh oleh investor. Perkembangan aktivitas pasar modal membawa perubahan besar pada tuntutan akan kualitas informasi. Informasi ini sangat dibutuhkan investor untuk mengurangi ketidakpastian dalam pembuatan keputusan. Keputusan investasi oleh investor merupakan reaksi atas informasi yang diterima. Investor memerlukan informasi guna memperoleh bayangan mengenai hasil yang diharapkan dan risiko terkait dengan aktivitas investasi yang dilakukan. Para investor akan bereaksi terhadap suatu pengumuman di pasar modal apabila hal tersebut memiliki kandungan informasi yang membawa sinyal berkualitas dan dapat dipercaya.

Salah satu informasi yang ada dipasar modal dan dipublikasikan adalah stock split. Stock split adalah sebuah aksi korporasi yang dilakukan perusahaan yang telah go public (emiten) dengan menaikan jumlah lembar saham yang beredar. Harga per-lembar saham baru sesudah pemecahan saham ialah sebesar 1/n dari harga saham sebelumnya. Dengan demikian, sebetulnya pemecahan saham tidak menambah nilai dari perusahaan atau dengan kata lain pemecahan 
saham tidak memiliki nilai ekonomis. Pada dasarnya, stock split adalah aksi korporasi yang mempengaruhi jumlah saham yang beredar, tetapi tidak mempengaruhi kapitalisasi pasar perusahaan atau kekayaan pemegang saham yang ada. Dengan demikian, dengan stock split perusahaan meningkatkan jumlah saham yang beredar dengan rasio tertentu dan akibatnya harga per saham turun dengan rasio peningkatan jumlah saham (Ujkan dan Burim, 2012).

Menurut Leung et al. (2005) perpecahan dapat diinterpretasikan oleh pasar modal sebagai sinyal optimisme manajemen tentang masa depan. Stock split memberikan informasi kepada investor tentang prospek peningkatan return sehingga harga saham akan naik pada saat pengumuman. Pengumuman stock split dapat memberikan sinyal informasi yang berguna bagi investor untuk melakukan keputusan. Signaling theory menyatakan bahwa setiap aksi korporasi yang dilakukan sebuah perusahaan memiliki potensi kandungan informasi sebagai suatu sinyal (Pratama dan Sudhiarta, 2014). Signaling theory didasari bahwa terdapat asimetri informasi antara manajemen perusahaan dengan investor, dimana pihak perusahaan memiliki informasi lebih baik mengenai perusahaannya akan terdorong untuk menyampaikan informasi tersebut kepada calon investor.

Permintaan atau pembelian harga saham kadang kala dapat menurun dikarenakan harga yang terlalu tinggi. Untuk mengatasi hal tersebut perusahaan melakukan suatu tindakan yaitu stock split untuk menurunkan harga saham. Meskipun secara teoretis pemecahan saham tidak memiliki nilai ekonomis, namun banyak peristiwa pemecahan saham di pasar modal menunjukkan bahwa pemecahan saham merupakan peristiwa yang penting dalam praktik pasar modal. 
Harga saham yang murah akan menyebabkan investor membelinya sehingga akan meningkatkan volume perdagangan saham yang dapat memberikan abnormal return bagi investor.

Pengumuman stock split dapat mempengaruhi reaksi pasar, tergantung ada atau tidaknya kandungan informasi pada pengumuman stock split tersebut. Reaksi pasar ditunjukkan dengan adanya perubahan harga dari sekuritas yang bersangkutan, reaksi tersebut dapat diukur dengan abnormal return. Return taknormal (abnormal return) adalah selisih antara return sesungguhnya yang terjadi dengan return ekspektasian (Jogiyanto, 2015:647). Selisih dari kedua return dapat berupa selisih positif dan selisih negatif. Jika abnormal return positif maka actual return atau return yang sesungguhnya lebih besar dari return yang diharapkan oleh investor.

Sebelum melakukan stock split, manajemen perusahaan akan merencakan terlebih dahulu untuk melakukan split saham dan akan diusulkan dalam RUPS. Hasil dari RUPS ini akan diumumkan secara resmi melalui surat kabar dan pemberitahuan manajemen perusahaan kepada pihak Bapepam serta Bursa Efek (Mohammad, 2006:273). Peraturan yang dikeluarkan BAPEPAM-LK mewajibkan setiap perusahaan dalam memberikan informasi terlebih dahulu kepada media sebelum menyelenggarakan sebuah RUPS yang dimaksudkan agar para pemegang saham baik mayoritas maupun minoritas mengetahui apa yang sedang perusahaan rencanakan dalam waktu dekat ini dan juga untuk memberikan informasi lebih mengenai langkah apa yang yang sebaiknya investor lakukan. Baik itu para 
pemilik perusahaan tersebut ataupun para investor yang lain yang berminat dalam melakukan investasi di pasar modal.

Wulff (1999) meneliti reaksi pasar terhadap stock split pada perusahaan di Jerman, ia menemukan abnormal return yang signifikan di sekitar pengumuman. Penelitian Wulff (1999) menunjukan hasil bahwa terdapat abnormal return yang signifikan saat dan setelah peristiwa stock split. (Savitri dan Martani, 2006) melakukan penelitian mengenai stock split, hasil dari penelitian tersebut menunjukkan bahwa abnormal return pada 5 hari sebelum dan pada tanggal pengumuman berubah secara signifikan.

Penelitian yang dilakukan (Mila, 2010) menunjukan tidak terdapat pengaruh signifikan rata-rata abnormal return saham sebelum dan sesudah stock split. Ini berarti abnormal return tidak mendapat reaksi dari pasar. (Ginting dan Rahyuda, 2013) meneliti mengenai perbedaan volume perdagangan saham dan abnormal return sebelum dan sesudah stock split menemukan hasil bahwa volume perdagangan saham sebelum dan sesudah stock split berbeda secara signifikan serta tidak ditemukannya perbedaan perolehan abnormal return yang signifikan sebelum dan sesudah stock split. Penelitian yang dilakukan oleh Liogu dan Saerang (2015) menunjukan bahwa di seputar pengumuman stock split investor tidak memperoleh abnormal return yang signifikan di seputar pengumuman.

Banyak penelitian yang telah dilakukan mengenai stock split dan memperoleh hasil yang berbeda. Berdasarkan hal yang telah dipaparkan diatas, maka peneliti melakukan pengujian kembali reaksi pasar atas pengumuman stock 
split di Bursa Efek Indonesia. Penelitian ini memiliki tujuan untuk mengetahui apakah peristiwa pengumuman stock split akan direaksi oleh pasar.

Tujuan penelitian ini adalah untuk menguji kembali dan memperoleh bukti empiris mengenai reaksi pasar yang diukur dengan abnormal return atas pengumuman stock split. Penelitian ini mengembangkan bidang ilmu akuntansi, khususnya yang berkaitan dengan pasar modal. Penelitian ini memberikan bukti empiris signaling theory, serta mendukung hasil-hasil penelitian sebelumnya dan diharapkan dapat menjadi tambahan referensi bagi penelitian selanjutnya. Hasil dari penelitian ini memberikan kontribusi pemikiran kepada pembaca dan sebagai bahan pertimbangan bagi manajemen perusahaan yang sudah go public sebagai dasar pengambilan keputusan. Bagi investor, penelitian ini menjadi bahan pertimbangan dan masukan dalam mengambil keputusan pada saat melakukan pembelian dan penjualan saham ketika terjadi peristiwa pengumuman stock split.

Teori sinyal berargumen bahwa pemecahan saham menunjukkan bahwa stock split menyampaikan informasi positif kepada investor tentang profitabilitas masa depan perusahaan (Copeland, 1981).Stock split memberikan informasi kepada investor tentang prospek peningkatan return sehingga harga saham akan naik pada saat pengumuman. Dengan melihat bahwa perusahaan akan memberikan return yang tinggi, akan menarik minat investor untuk melakukan investasi. Teori signaling berargumen bahwa pemecahan saham menunjukan sinyal optimisme manajemen akan mampu meningkatkan kembali harga saham di masa datang (Tandelilin, 2010:570). 
Marwata (2001) berpendapat bahwa stock split dianggap sebagai tindakan manajemen untuk memberikan sinyal kepada publik bahwa perusahaan memiliki prospek yang bagus di masa yang akan datang. Stock split memberikan informasi mengenai kemungkinan return dimana return tersebut merupakan sinyal laba jangka pendek dan jangka panjang. Pemecahan saham adalah upaya perusahaan untuk menarik perhatian investor. Stock split seharusnya memiliki sinyal yang valid karena tidak semua perusahaan bisa melakukannya karena pemecahan saham mengandung biaya yang harus ditanggung oleh perusahaan yang melakukannya.

Stock split merupakan salah satu bentuk informasi yang diberikan oleh emitem untuk menaikan jumlah saham yang beredar. Pemecahan saham (stock split) adalah memecah selembar saham menjadi $\mathrm{n}$ lembar saham. Harga per lembar saham baru setelah stock split adalah sebesar 1/n dari harga sebelumnya. Dengan demikian, sebenarnya stock split tidak menambah nilai dari perusahaan atau dengan kata lain stock split tidak mempunyai nilai ekonomis. Misalnya jumlah saham yang beredar adalah 1 juta lembar dengan nilai Rp 1.000,- per lembar. Nilai ekuitas perusahaan adalah sebesar 1 juta x Rp 1.000,- = Rp 1 miliar. Perusahaan memecah dari satu lembar saham untuk dijadikan sebanyak 2 lembar saham, sehingga harga per lembar saham baru adalah menjadi Rp 500,- dan jumlah saham beredar menjadi sebanyak 2 juta lembar. Nilai ekuitas perusahaan tidak berubah, yaitu tetap sebesar 2 juta x Rp 500,- = Rp 1 miliar.

Pemecahan saham mengakibatkan bertambahnya jumlah lembar saham yang beredar sesuai dengan rasio stock split yang ditentukan. Meskipun pada dasarnya 
peristiwa pemecahan saham ini tidak memiliki nilai ekonomis, perusahaan perlu melakukan tindakan tersebut bilamana harga saham di pasar dinilai terlalu tinggi, sehingga mengurangi minat investor untuk membelinya. Banyaknya peristiwa stock split di pasar modal memberikan indikasi bahwa stock split merupakan alat yang penting dalam praktik pasar modal. Stock split menjadi salah satu alat manajemen untuk membentuk harga pasar perusahaan, dan dalam praktik di pasar modal apabila perusahaan tersebut mempunyai kinerja yang bagus maka harga akan meningkat lebih cepat.

Brown dan Warner (1985) dalam (Jogiyanto, 2015:648) mengestimasi return ekspetasian menggunakan model estimasi mean-adjusted model, market model dan market-adjusted model. Mean Adjusted Model menganggap return ekspektasi bernilai konstan yang sama dengan rata-rata return realisasi sebelumnya selama periode estimasi (estimation period). Model ini dirumuskan sebagai berikut:

$$
\mathrm{E}\left[\mathrm{R}_{\mathrm{i}, \mathrm{t}}\right]=\frac{\sum \mathrm{R}_{\mathrm{i}, \mathrm{j}}}{\mathrm{T}}
$$

\section{Keterangan:}

$$
\begin{array}{ll}
\mathrm{E}\left[\mathrm{R}_{\mathrm{i}, \mathrm{t}}\right] & =\text { return ekspektasian sekuritas ke-i pada periode peristiwa ke } \mathrm{t} \\
\mathrm{R}_{\mathrm{i}, \mathrm{j}} & =\text { return realisasi sekuritas ke-i pada periode estimasi ke-j } \\
\mathrm{T} & =\text { lamanya periode estimasi }
\end{array}
$$

Periode estimasi (estimation period) umumnya merupakan periode sebelum periode peristiwa. Periode peristiwa (event period) disebut juga dengan periode pengamatan atau jendela peristiwa (event window).

Perhitungan return ekspektasi dengan model pasar (Market Model) ini dilakukan dengan dua tahap, yaitu (1) membentuk model ekspektasi dengan 
menggunakan data realisasi selama periode estimasi dan (2) menggunakan model ekspektasi ini untuk mengestimasi return ekspektasi di periode jendela. Model ekspektasi dapat dibentuk menggunakan teknik regresi OLS (Ordinary Least Square) dengan persamaan:

$$
R_{i, j}=\alpha_{i}+\beta_{i} \cdot R_{m j}+\varepsilon_{i, j}
$$

Keterangan:

$R_{i, j} \quad=$ return realisasi sekuritas ke-i pada periode estimasi ke-j

$\alpha_{i} \quad=$ intercept untuk sekuritas ke-i

$\beta_{\mathrm{i}} \quad=$ koefisien slope yang merupakan Beta dari sekuritas ke-i

$R_{m j} \quad=$ return indeks pasar pada periode estimasi ke-j yang dapat dihitung dengan rumus $\mathrm{R}_{\mathrm{mj}}=\left(\mathrm{IHSG}_{\mathrm{j}}-\mathrm{IHSG}_{\mathrm{j}-1}\right) / \mathrm{IHSG}_{\mathrm{j}-1}$

$\varepsilon_{i, j} \quad=$ kesalahan residu sekuritas ke-i pada periode estimasi ke $\mathrm{j}$.

Model sesuaian-pasar (Market Adjusted Model) menganggap bahwa penduga yang terbaik untuk mengestimasi return suatu sekuritas adalah return indeks pasar saat tersebut. Dengan menggunakan model ini, tidak perlu menggunakan periode estimasi untuk membentuk model estimasi karena return sekuritas yang diestimasi sama dengan return indeks pasar. Rumus untuk menghitung Market Adjusted Model adalah:

$A R_{i, t}=R_{i, t}-R_{m, t}$

Keterangan :

$\mathrm{AR}_{\mathrm{i}, \mathrm{t}}=$ abnornomal return saham i pada hari ke $\mathrm{t}$

$\mathrm{R}_{\mathrm{i}, \mathrm{t}} \quad=$ actual return untuk saham i pada hari ke $\mathrm{t}$

$\mathrm{R}_{\mathrm{M}, \mathrm{t}} \quad=$ return pasar pada hari ke $\mathrm{t}$

Studi peristiwa (even study) merupakan studi yang mempelajari reaksi pasar terhadap suatu peristiwa (event) yang informasinya dipublikasikan sebagai suatu pengumuman. Even study dapat digunakan untuk menguji kandungan informasi (information content) dari suatu pengumuman dan dapat juga digunakan untuk 
menguji efisiensi pasar bentuk setengah kuat. Jika pengumuman mengandung informasi (information content), maka pasar diharapkan akan bereaksi pada waktu pengumuman tersebut diterima oleh pasar. Reaksi pasar ditandai dengan terjadinya perubahan harga sekuritas yang bersangkutan. Reaksi seperti ini bisa diukur dengan menggunakan abnormal return. Apabila abnormal return digunakan untuk mengukur reaksi tersebut maka suatu pengumuman yang mengandung informasi diperkirakan dapat memberikan abnormal return kepada pasar. Sebaliknya apabila pengumuman tidak mengandung informasi maka dapat dikatakan tidak memberikan abnormal return pada pasar. Dari pengertian tersebut sebenarnya event study dapat digunakan untuk melihat reaksi pasar modal (dengan pendekatan pergerakan harga saham) terhadap suatu peristiwa tertentu.

Abnormal return merupakan selisih return sesungguhnya (actual return) dengan return ekspektasi (expected return). Menurut (Jogiyanto, 2015:647) abnormal return merupakan kelebihan dari return yang sesungguhnya terjadi terhadap normal (return ekspektasi). Abnormal return positif artinya tingkat keuntungan yang sebenarnya terjadi lebih besar dari tingkat keuntungan yang diharapkan. Sedangkan abnormal return negatif berarti tingkat keuntungan yang sebenarnya terjadi lebih kecil dari tingkat keuntungan yang diharapkan. Para investor tentunya mengharapkan return yang akan diterima proporsional dengan pengorbanan yang dikeluarkan, akan tetapi dalam prakteknya tidaklah selalu demikian. Seringkali investor dihadapkan pada kenyataan di mana return yang diharapkan tidak sesuai dengan return yang diterimanya. Fenomena inilah yang dikenal dengan istilah abnormal return, yang dihitung dari selisih antara return 
yang sesungguhnya terjadi (actual return) dengan return yang diharapkan oleh investor (expected return).

Berdasarkan landasan teori dan kajian empiris penelitian sebelumnya, maka peneliti merumuskan kerangka konsep penelitian seperti pada Gambar 1 sebagai berikut.

\begin{tabular}{|l|l}
\hline Pengumuman & Uji t \\
\cline { 2 - 2 }
\end{tabular}

\section{Gambar 1. Kerangka Konseptual Penelitian}

Sumber: Data diolah, 2018

Return saham merupakan hasil atau keuntungan yang diperoleh pemegang saham sebagai hasil dari investasinya. Kinerja perusahaan yang baik akan membuat investor mengharapkan memperoleh return yang maksimal. Pengumuman stock split akan memberikan sinyal positif karena para investor menilai saham perusahaan tersebut sangat menguntungkan. Kebijakan untuk melakukan stock split diputuskan melalui rapat umum pemegang saham (RUPS) atau rapat umum pemegang saham luar biasa (RUPSLB). Apabila kebijakan tersebut disetujui oleh para pemegang saham, maka keputusan untuk melakukan stock split akan diumumkan ke publik. Berdasarkan teori sinyal pemecahan saham menunjukkan bahwa stock split menyampaikan informasi positif kepada investor tentang profitabilitas masa depan (Copeland, 1981). Teori signaling berargumen bahwa pemecahan saham menunjukan sinyal optimisme manajemen akan mampu meningkatkan kembali harga saham di masa datang (Tandelilin, 2010:570). Manajer dapat menggunakan pemecahan saham untuk sinyal informasi positif ke pasar tentang harapan masa depan perusahaan. Alasannya adalah bahwa 
Putu Gede Aditama Putra dan I Gusti Ngurah Agung Suaryana. Reaksi ...

para eksekutif hanya akan melakukan stock split jika mereka yakin bahwa perusahaan akan berjalan dengan baik di masa depan.

Dampak stock split terhadap keuntungan investor dijelaskan oleh Grinblatt et al. 1984) bahwa disekitar pengumuman split menunjukkan adanya perilaku harga saham yang abnormal sehingga mempengaruhi keuntungan (return) saham untuk investor. Penelitian yang dilakukan oleh Liogu dan Saerang (2015) menunnjukan bahwa di seputar pengumuman stock split investor tidak memperoleh abnormal return yang signifikan di seputar pengumuman.

Berdasarkan hal tersebut, maka diajukan hipotesis sebagai berikut:

$\mathrm{H}_{1}$ : Terdapat reaksi pasar atas pengumuman stock split.

\section{METODE PENELITIAN}

Lokasi dalam penelitian ini dilakukan pada perusahaan yang terdaftar di Bursa Efek Indonesia yang melakukan stock split pada periode 2013-2017 dengan

Mengakses website situs resmi www.idx.co.id, finance.yahoo.com dan www.sahamok.com. Objek penelitian ini adalah abnormal return perusahaan yang melakukan aktivitas stock split pada tahun 2013-2017.

Abnormal return adalah selisih return sesungguhnya (actual return) dengan return yang diharapkan (expected return). Perhitungan expected return dalam penelitian ini menggunakan Market Adjusted Model, karena memberikan kemudahan dalam melakukan deteksi terhadap abnormal return. Menurut Jogiyanto (2015:659) dengan menggunakan model ini, maka tidak perlu menggunakan periode estimasi untuk membentuk model estimasi, karena return sekuritas yang diestimasi adalah sama dengan return indeks pasar. Market 
Adjusted Model mempunyai potensi yang cukup besar dalam menghasilkan tes statistik yang kuat dibandingkan dengan model statistik lainnya yaitu mean adjusted model dan market model. Abnormal return digunakan untuk mengukur reaksi pasar terhadap suatu kandungan informasi dalam pengumuman. Langkahlangkah perhitungan rata-rata abnormal return adalah sebagai berikut:

Menghitung actual return (return sesungguhnya) masing-masing sampel dengan rumus:

$$
R_{i, t}=\frac{P_{i, t}-P_{i, t-1}}{P_{i, t-1}}
$$

Keterangan:

$R_{i, t} \quad=$ Return sesungguhnya yang terjadi untuk sekuritas ke-i pada periode peristiwa ke-t.

$P_{i, t} \quad=$ Harga sekarang relatif.

$P_{i, t-1}=$ Harga sebelumnya .

Menghitung expected return (return ekspektasi) masing-masing sampel dengan rumus:

$$
\mathrm{R}_{m t}=\frac{I H S G_{t}-I H S G_{t-1}}{I H S G_{t-1}}
$$

Keterangan:

$\mathrm{R}_{\mathrm{mt}} \quad=$ Return pasar pada waktu ke-t.

$\mathrm{IHSG}_{\mathrm{t}}=$ Indeks Harga Saham Gabungan hari ke-t

$\mathrm{IHSG}_{\mathrm{t}-1}=$ Indeks Harga Saham Gabungan hari ke- $\mathrm{t}_{\mathrm{t}-1}$

Menghitung abnormal return untuk masing-masing sampel dengan rumus:

$$
\mathrm{AR}_{\mathrm{it}} \quad=\mathrm{R}_{\mathrm{it}}-\mathrm{E}_{\mathrm{Rt}}
$$

Keterangan: 
$\mathrm{AR}_{\mathrm{it}}=$ Abnormal Return

$\mathrm{R}_{\mathrm{it}} \quad=$ Actual Return

$\mathrm{E}_{\mathrm{Rt}} \quad=$ Expected Return

Menghitung cumulative abnormal return masing-masing sampel dengan rumus:

$$
\mathrm{ARTN}_{\mathrm{i}, \mathrm{t}}=\sum_{\mathbf{a}=\mathbf{t} \mathbf{3}}^{\mathrm{t}} \mathbf{R T N}_{\mathrm{i}}
$$

Keterangan:

$$
\begin{array}{ll}
\text { ARTN }_{\mathrm{i}, \mathrm{t}} & =\text { akumulasi return tak normal sekuritas ke-i } \\
\mathrm{RTN}_{\mathrm{i}, \mathrm{a}} & =\text { return tak normal untuk sekuritas ke-i }
\end{array}
$$

Rentang waktu yang dipakai adalah 7 hari pengamatan yakni 3 hari sebelum dilakukannya pengumuman stock split, hari pengumuman stock dan 3 hari sesudah dilakukannnya pengumuman stock split. Dimana rentang waktu ini dipilih karena rentang waktu 3 hari sebelum dan 3 hari sesudah dianggap sebagai batas investor akan bereaksi secara aktif terhadap informasi pengumuman stock split perusahaan. Rentang waktu tersebut juga dianggap sebagai rentang waktu dimana tingkat reaksi investor terhadap peristiwa tersebut paling tinggi. Jika rentang waktunya terlalu lama diperkirakan reaksi investor mengenai informasi pengumuman stock split akan dipengaruhi oleh faktor lain, seperti pembagian dividen, penerbitan saham, pembelian kembali saham perusahaan dan faktorfaktor eksternal (Sukartha, 2015).

Populasi adalah wilayah generalisasi yang terdiri atas obyek atau subyek yang mempunyai kualitas atau karakteristik tertentu yang ditetapkan oleh peneliti untuk dipelajari dan kemudian ditarik kesimpulannya (Sugiyono, 2014:115). 
Populasi dalam penelitian ini adalah perusahaan-perusahaan yang terdaftar di Bursa Efek Indonesia yang melakukan stock split pada periode 2013-2017.

Sampel adalah bagian dari jumlah karakteristik yang dimiliki oleh populasi tersebut (Sugiyono, 2014:116). Teknik penentuan sampel dalam penelitian ini menggunakan nonprobability purposive sampling, yaitu teknik pengambilan sampel dengan pertimbangan tertentu (Sugiyono, 2014: 122). Adapun kriteria yang digunakan dalam pengambilan sampel sebagai berikut: 1). Data harga saham harian dan data IHSG tersedia secara lengkap untuk dianalisis; Perusahaan tidak mengeluarkan kebijakan lain selama periode pengamatan seperti stock dividend (dividen saham), dividen tunai, right issue, dan bonus shares (saham bonus) selama periode pengamatan.

Adapun sumber data yang dipergunakan dalam penelitian ini adalah data sekunder. Data sekunder merupakan sumber data penelitian yang diperoleh peneliti secara tidak langsung melalui media perantara. Adapun data yang digunakan dalam penelitian ini adalah sebagai berikut: 1). Daftar perusahaan yang melakukan aktivitas stock split diperoleh dari situs www.idx.co.id dan www.sahamok.com; 2). Tanggal RUPS di peroleh dari annual report masingmasing perusahaan; 3). Data harga saham harian dan data IHSG diperoleh melalui situs www.idx.co.id, finance.yahoo.com dan www.sahamok.com.

Metode observasi nonpartisipan dalam penelitian ini dilakukan dengan cara mencatat abnormal return perusahaan yang datanya dapat diakses dalam situs situs resmi Bursa Efek Indonesia (ww.idx.co.id), finance.yahoo.com dan www.sahamok.com. Data kuantitatif yang digunakan dalam penelitian ini adalah 
olahan data yang digunakan untuk menghitung besarnya abnormal return saham pada perusahaan yang terdaftar di Bursa Efek Indonesia. Data kualitatif yaitu data yang berbentuk kata, kalimat, skema, dan gambar (Sugiyono, 2014:13). Data kualitatif dalam penelitian ini adalah daftar perusahaan yang melakukan stock split yang terdaftar di Bursa Efek Indonesia pada Periode 2013-2017.

Teknik analisis data yang dilakukan yakni pertama dilakukan uji statistic deskripstif dalam penelitian ini disajikan untuk memberikan informasi mengenai abnormal return peristiwa pengumuman stock split. Uji statistik deskriptif diperlukan untuk memberi gambaran data yang dilihat dari nilai rata-rata (mean), nilai minimum dan nilai maksimum, serta simpangan baku. Kemudian uji asumsi klasik yang meliputi uji normalitas digunakan untuk menentukan apakah data yang dipergunakan dalam penelitian ini berdistribusi normal atau tidak. Deteksi terhadap normalitas data pada penelitian ini dilakukan dengan uji kolmogorovsmirnov test. Syarat dari uji normalitas adalah asymp. Sig. (2-tailed) >0,05, maka data dikatakan berdistribusi normal. Begitu sebaliknya, data dikatakan tidak berdistribusi normal apabila asymp. Sig. $(2$-tailed $)<0,05$.

Uji-t digunakan untuk melihat signifikansi return tak normal yang ada di periode peristiwa. Signifikansi yang dimaksud adalah bahwa abnormal return tersebut secara statistik signifikan tidak sama dengan nol (positif untuk kabar baik dan negatif untuk kabar buruk) (Jogiyanto, 2015:666). Uji ini dilakukan untuk menguji ada tidaknya reaksi pasar atas pengumuman stock split. Jika nilai probabilitas > 0,05 maka hipotesis nol diterima dan sebaliknya jika nilai probabilitas $<0,05$ maka hipotesis nol ditolak. 


\section{HASIL DAN PEMBAHASAN}

Sampel yang digunakan dalam penelitian ini dipilih dengan menggunakan metode nonprobability purposive sampling yang ditentukan berdasarkan kriteria-kriteria tertentu. Kriteria yang dipilih sebagai subyek penelitian adalah perusahaan yang melakukan pengumuman stock split serta datanya tersedia yang meliputi harga saham perusahaan dan indeks harga saham gabungan. Data yang digunakan dalam penelitian ini adalah data perusahaan yang terdaftar di Bursa Efek Indonesia yang melakukan pengumuman stock split tahun 2013-2017.

Tabel 1. Seleksi Sampel Penelitian

\begin{tabular}{|c|c|c|}
\hline \multirow{2}{*}{ No. } & \multirow{2}{*}{ Kriteria Sampel } & Stock split \\
\hline & & Pengumuman \\
\hline 1 & $\begin{array}{l}\text { Perusahaan terdaftar di BEI yang } \\
\text { melakukan pengumuman stock split 2013- }\end{array}$ & 69 \\
\hline 2 & 2017 & \\
\hline & Perusahaan mengeluarkan kebijakan lain & 2 \\
\hline 3 & selama periode pengamatan & 2 \\
\hline & Data tidak tersedia & 65 \\
\hline & Perusahaan yang memenuhi kriteria & \\
\hline
\end{tabular}

Berdasarkan hasil statistik deskriptif menunjukan bahwa cumulative abnormal return (CAR) pengumuman stock split secara keseluruhan dengan 65 perusahaan selama 7 hari pengamatan memiliki nilai minimum sebesar $-0,2065$ dan nilai maksimum sebesar 0,2802. Rata-rata CAR sebesar 0,024048 dengan standar devisiasi 0,0865806. Nilai CAR yang positif menunjukan secara umum, selama periode pengamatan menghasilkan return yang positif. Sebelum menguji hipotesis, hal pertama yang dilakukan yaitu uji normalitas data yang bertujuan untuk melihat apakah data berdistribusi normal atau tidak. Untuk mendeteksi normalitas data dapat dilakukan dengan uji statistik Kolmogorov-Smirnov. Sampel 
berdistribusi normal jika probabilitas signifikansi $>\alpha=5 \%$. Uji KolmogorovSmirnov CAR pengumuman stock split menunjukan bahwa probabilitas signifikansi sebesar 0.084 . Nilai signifikansi tersebut di atas $\alpha=0,05$, hal ini dapat dikatakan data bersifat normal.

Berdasarkan hasil uji normalitas telah diketahui bahwa data berdistribusi normal, maka pengujian hipotesis menggunakan One Sample t-test. Pengujian statistik ini dilakukan untuk menguji apakah terdapat reaksi pasar atas pengumuman stock split. Hasil pengujian hipotesis disajikan pada Tabel 2 berikut ini.

Tabel 2.

One Sample t-test

\begin{tabular}{|c|c|c|c|c|c|c|}
\hline & \multicolumn{6}{|c|}{ Test Value $=0$} \\
\hline & \multirow[t]{2}{*}{$\mathrm{t}$} & \multirow[t]{2}{*}{$\mathrm{df}$} & \multirow[t]{2}{*}{$\begin{array}{l}\text { Sig. } \\
(2- \\
\text { tailed })\end{array}$} & \multirow[t]{2}{*}{$\begin{array}{c}\text { Mean } \\
\text { Difference }\end{array}$} & \multicolumn{2}{|c|}{$\begin{array}{l}\text { 95\% Confidence } \\
\text { Interval of the } \\
\text { Difference }\end{array}$} \\
\hline & & & & & Lower & Upper \\
\hline CAR & 2,239 & 64 & 0,029 & 0,0240480 & 0,002594 & 0,045502 \\
\hline
\end{tabular}

Sumber: Data diolah, 2018

Tabel 2. menjelaskan ringkasan hasil pengujian cumulative abnormal return di sekitar tanggal pengumuman, yaitu tiga hari sebelum, pada saat dan tiga hari sesudah pengumuman. Pengujian dilakukan dengan menggunakan one sample ttest. Berdasarkan tampilan Tabel 2 diatas, menunjukkan bahwa cumulative abnormal return $(\mathrm{CAR})$ pengumuman stock split memperoleh nilai $\mathrm{t}=2,239$ dengan probabilitas sebesar $0,029<\alpha(0,05)$ yang berarti hipotesis diterima, artinya terdapat reaksi pasar yang signifikan atas pengumuman stock split.

Reaksi pasar tercermin dalam nilai cumulative abnormal return (CAR). Hasil pengujian hipotesis melalui uji one sample-test, memperlihatkan bahwa nilai 
probabilitas $0,029<\alpha(0,05)$ yang artinya bahwa hipotesis diterima. Dari uji tersebut, dapat disimpulkan terdapat reaksi pasar atas pengumuman stock split. Rata-rata CAR selama 7 hari pengamatan sebesar 0,0240480 yang berarti pasar bereaksi positif atas pengumuman stock split. Berdasarkan hasil diatas dapat dikatakan bahwa peristiwa pengumuman stock split mendapat reaksi dari para investor. Investor memandang bahwa pengumuman stock split membawa informasi yang positif (good news). Hal tersebut diindikasikan dengan adanya abnormal return atas pengumuman stock split. Ini sesuai dengan teori sinyal yang menyatakan stock split menyampaikan informasi positif kepada investor tentang profitabilitas masa depan perusahaan. Sinyal positif inilah yang membuat investor tertarik untuk memiliki saham-saham perusahaan yang akan melakukan stock split. Ketertarikan ini akan meningkatkan harga saham dan pada akhirnya akan menimbulkan abnormal return di pasar.

Hasil penelitian ini sejalan dengan penelitian Grinblatt et al. (1984) yang menunjukan bahwa disekitar pengumuman split menunjukkan adanya perilaku harga saham yang abnormal sehingga mempengaruhi keuntungan (return) saham untuk investor. Penelitian Griffin (2010) menemukan abnormal return yang signifikan atas pengumuman stock split. Ini dapat dijelaskan dengan teori sinyal dimana investor melihat perpecahan saham sebagai suatu tanda manajemen perusahaan tentang peningkatan probabilitas masa depan perusahaan. Eksekutif perusahaan memperkirakan harga saham akan terus meningkat dalam waktu dekat dan merasa harus melakukan stock split. Penelitian yang dilakukan Meylitas dan Yasa (2015) menunjukkan terdapat abnormal return yang signifikan atas 
peristiwa stock split. Stock split mendapatkan respon dari para investor. Stock split memiliki kandungan informasi ketika informasi tersebut direspon oleh pelaku pasar. Informasi pemecahan saham ini dinilai memiliki kandungan informasi dan menjadi bermakna ketika informasi tersebut direspon oleh para investor. Adanya abnormal return di sekitar peristiwa stock split menunjukkan reaksi pasar signifikan yang ditunjukkan oleh pelaku pasar. Namun, hasil penelitian ini bertentangan dengan penelitian Liogu dan Saerang (2015) yang menyatakan bahwa di seputar pengumuman stock split investor tidak memperoleh abnormal return yang signifikan. Hal ini menunjukkan bahwa investor memiliki preferensi yang sama terhadap stock split yang akan dilakukan emiten, dimana stock split tidak akan menyebabkan perubahan pada kesejahteraan pemegang saham, karena nilai saham yang dimiliki investor tetap setelah dilakukan stock split.

Hasil Penelitian ini secara teoretis dapat memberikan bukti empiris yang menguatkan grand theory bahwa informasi yang dipublikasikan emiten direaksi oleh pasar, yang menunjukkan bahwa hal tersebut memiliki kandungan informasi. Penelitian ini memberikan tambahan informasi secara empiris mengenai adanya reaksi pasar atas pengumuman stock split. Setiap informasi yang diterima atau didapatkan oleh setiap pelaku pasar diharapkan untuk dianalisa terlebih dahulu, sehingga memperoleh keputusan investasi yang tepat dan berpotensi memberikan tingkat pengembalian yang maksimal. Hasil penelitian ini secara praktis dapat menjadi pertimbangan bagi investor untuk lebih cermat dan berhati-hati dalam menghadapi setiap corporate action yang dilakukan oleh perusahaan. Hasil penelitian ini mampu untuk memberikan gambaran mengenai adanya perilaku dari 
pelaku pasar dalam bertindak pada saat peristiwa pengumuman stock split periode 2013-2017.

\section{SIMPULAN}

Berdasarkan hasil analisis dan pembahasan yang telah dilakukan sebelumnya, dapat simpulan sebagai berikut: selama 7 hari perdagangan saham di sekitar pengumuman stock split dengan menggunakan variabel cumulative abnormal return tanpa melibatkan pengumuman selain stock split. Hasil uji one sample ttest menghasilkan terdapat reaksi pasar atas pengumuman stock split yang diukur dengan abnormal return dengan nilai probabilitas $0,029<$ a $(0,05)$. Hal ini sesuai dengan Signaling Theory menyatakan bahwa pemecahan saham menunjukkan bahwa stock split menyampaikan informasi positif kepada investor tentang profitabilitas masa depan perusahaan. Ini berarti bahwa pengumuman stock split memiliki kandungan informasi bagi investor.

Adapun saran yang dapat diberikan yakni bagi investor peristiwa pengumuman stock split ini dapat digunakan sebagai informasi dalam pengambilan keputusan untuk melakukan investasi karena pengumuman stock split direaksi oleh pasar. Bagi perusahaan dapat menggunakan informasi dari penelitian ini terkait keputusan untuk mengambil kebijakan stock split. Walau secara ekonomis stock split tidak berpengaruh bagi perusahaan tetapi dalam penelitian ini stock split direspon oleh pasar. 


\section{REFERENSI}

Bajra, Ujkan and Burim Hasani. 2012. Event Study on Stock Splits. International Journal of Interdisciplinary Research, 1(2).

Bhattacarya, Utpal and Amy Dittmar. 2001. Costless versus costly signaling in capital markets: theory and Evidence. Indiana/MIT and Michigan University Working Paper.

Bodhanwala, Ruzbeh J. 2016. Stock Split and Reverse Split-Evidence from India. Great Lakes Institute of Management, 10(2), hal. 26-41.

Brown, S.J. \& J.B. Warner. 1985. Using Daily Stock Returns: The Case of Event Studies. Journal of Fiancial Economics, 14, pp. 3-31.

Brennan, M. J. and T. E. Copeland. 1988. Stock Split, Stock Price, and Transaction Costs. Journal of Financial Economics UCLA, 22, pp. 83-101

Budatama, I P. Niko dan Ni Kt. Lely Aryani Merkusiwati. 2014. Reaksi Pasar Berupa Volume Perdagangan Saham Saat Stock Split pada Perusahaan BEI Tahun 2011-2013. E-Jurnal Akuntansi Universitas Udayana, 9(1), hal.106117.

Copeland, T. E. (1981). Financial Theory and Corporate Policy. Journal of Banking \& Finance (Vol. 5). https://doi.org/10.1016/0378-4266(81)90050-9

Firmansyah, Alfian Dody. 2016. Analisis Perbandingan Trading Volume Activity dan Abnormal Return Sebelum Sesudah Stock Split. Jurnal Ilmu dan Riset Manajemen, 5(5)

Fortuna, C.H.R. 2010. Analisis Pengaruh Stock Split Terhadap Harga Saham pada Perusahaan Go Public di Bursa Efek Indonesia. E-jurnal Universitas Diponegoro (UEJS). Id code:23220.

Ginting, S. C., \& Rahyuda, H. (2013). Perbedaan Volume Perdagangan Saham Dan Abnormal Return Sebelum Dan Sesudah Peristiwa Stock Split Pada Perusahaan. E-Jurnal Akuntansi Universitas Udayana, 1571-1589.

Griffin, C. H. (2010). Abnormal Returns and Stock Splits: The Decimalized vs . Fractional System of Stock Price Quotes. International Journal of Business and Management, 5(12), 3-13.

Grinblatt, M. S., Masulis, R. W., \& Titman, S. (1984). The valuation effects of stock splits and stock dividends. Journal of Financial Economics, 13(4), 461-490. https://doi.org/10.1016/0304-405X(84)90011-4 
Hendrawijaya Dj, Michael. 2009. Analisis Perbandingan Harga Saham, Volume Perdagangan Saham, dan Abnormal Return Saham Sebelum dan Sesudah Pemecahan Saham. E-jurnal Universitas Diponegoro (UEJS). Id code: 18157.

Hua, Liu, S. Ramesh. 2013. A Study on Stock Split Announcements and its Impact on Stock Prices in Colombo Stock Exchange (CSE) of Sri Lanka. Global Journal of Management Bussines Research Finance, 13(6).

Hossain, Md. Saimun. 2017. Market Reaction around the Event of a Stock Split: An Analysis on the Dhaka Stock Exchange. International Journal of Business and Management, Vol. 12, No. 7

Husnan, S. (1998). Dasar-dasar Teori Portofolio: Analisis Sekuritas di Pasar Modal (3rd ed.). Yogyakarta: YKPN.

Jogiyanto. (2015). Teori Portofolio dan Analisis Investasi (10th ed.). Yogyakarta: BPFE.

Kalay, Alon dan Mathias Kronlund. 2012. Stock Split: Information or Liquidity?. International jurnal of Business and Management.

Kurniawati, Indah, 2003, Analisa Kandungan Informasi Stock Split dan Likuiditas Harga Saham, Studi Empiris Pada Non-Sychronous Trading. Jurnal Riset Akuntansi Indonesia, Vol. 6, No. 3, Hal 264-275

Leung, T. Y., Rui, O. M., \& Wang, S. S. (2005). Do Stock Splits Really Signal? Working Paper (Vol. December).

Liogu, S. J., \& Saerang, I. S. (2015). Reaksi Pasar Modal Terhadap Pengumuman Kenaikan Harga BBM, 3(1), 1274-1282.

Marwata, U. G. (2001). Kinerja Keuangan Perusahaan Dan Keputusan Pemecahan Saham ( STOCK SPLITS ):, 16(4), 388-400.

MILAW, I. G. A. (2010). Analisis Pengaruh Pemecahan Saham (Stock Split) Terhadap Volume Perdagangan Saham Dan Abnormal Return Saham Pada Perusahaan Yang Terdaftar Di Bei Tahun 2007-2009. Journal of Finance, 1(1), 123-128.

Mohammad, S. (2006). Pasar Modal dan Manajemen Portofolio. Surabaya: Erlangga.

P, H. M., \& Yasa, G. W. (2015). Perbedaan Reaksi Pasar Atas Pengumuman Pemecahan Saham Pada Lq45 Dan Non Lq45, 10(2), 96-104. 
Pratama, I. G. S., \& Sudhiarta, G. M. (2014). Analisis Perbandingan Abnormal Return Saham Sebelum dan Sesudah Pengumuman Right Issue. E-Jurnal Manajemen Universitas Udayana, 3(1), 243-257.

Savitri, M., \& Martani, D. (2006). The Analysis Impact of Stock Splits and Reverse Share Splits on Share Return and Volume: The Case of Jakarta Stock Exchange, $C, 1-16$.

Sugiyono. (2014). Metode Penelitian Bisnis. Bandung: ALFABETA.

Sukartha, I. M. (2015). Reaksi Pasar Terhadap Pengumuman Saham Bonus di Bursa Efek Indonesia Fakultas Ekonomi Universitas Udayana ( Unud ), Bali , Indonesia dengan emiten untuk mentransaksikan sekuritas ( Tandelilin , 2010: 13 ). Transaksi dividen , merger, Initial public Offe, 1, 150-163. https://doi.org/10.1103/PhysRevLett.106.050401

Tandelilin. (2010). Portofolio dan Investasi. Yogyakarta: BPFE.

Tanjung, Abdul Haviz. 2007. Stock Split: Pengujian Terhadap Signalling dan Trading Range Pada Bursa Efek Jakarta. Jurnal Akuntansi dan Keuangan Indonesia, 4 (1).

Waelan. 2009. Pengaruh stock split terhadap future profitability dan likuiditas saham. Jurnal bisnis dan kewirausahaan. 5 (2), hal. 131-143.

Wulf, Christian. 2002. The Market Reaction to Stock Split-Evidence From Germany. Schmalenbach Business Review. Vol. 54, pp. 270-297.

Zhu, Chao and Kexin Chen. 2014. The Market Reaction to Stock Split Announcement and The Underlying Explanations. SFU Summit-Institutional Repository. 